\title{
Calvinist Miracles and the Concept of the Miraculous in Sixteenth-Century Huguenot Thought
}

MOSHE

SLUHOVSKY

Summary: This paper is a study of French Calvinism as a language. It was a language which employed the signifiers and the signs of the traditional Christian culture. There was persistent usages of key Catholic words in the theology of early Huguenot believers, regardless of their level of education or commitment to the cause. In an attempt to follow one such word ("miracle": miracula or mirabilia), a large number of texts are examined, including Calvin's own writings, the Histoire ecclésiastique, Simon Goulart's Mémoires de l'estat de France sous Charles Neufiesme, and the personal diary of an anonymous believer in the provincial town of Millau.

ixteenth-century Calvinism was shaped through controversy and confron $N$ tation, persecutions and sacrifices. Conversion to the new belief system meant sanctification, namely being turned around by God's grace and making a total commitment to one's new life. Acceptance of Calvin's teaching involved a rejection of established religions and social norms and behaviours, such as the veneration of saints, the adaptation of a new mode of everyday conduct, and adherence to new ceremonial and ritualistic religious practices. Calvinism, in other words, was more than what Jean Calvin wrote. For the followers of the Genevan theologian, far from being merely a theological interpretation of Scripture, Calvinism meant a way of life, a moral system, and a distinct culture. To be sure, Calvinism was never a monolithic cultural system. Dutch, Scottish, German and French followers developed different interpretations of Calvin's theology and distinct Calvinist traditions (and the discussion that follows deals only with the French variance). Yet, all shared a 
core of religious ideas - including a common rejection of late medieval Catholicism and a new scriptural interpretation of the Bible, based on Calvin's exegeses. ${ }^{1}$

From the definition of French Calvinism as a cultural system follows also a definition of French Calvinism as a language. ${ }^{2}$ It was a language which employed the signifiers and signs of the traditional language: its characters were Latin, its vocabulary both French and Latin. But during the religious conflicts of the second half of the sixteenth century, the ancient characters and words were deployed in a new setting, within a polemic context, to combat another language (and culture) which used the same signs and vocabulary. Furthermore, the entire Calvinist enterprise was grounded on careful rereadings of sanctified texts, and on "purification" of these texts from alleged misinterpretations. Indeed, Calvin and his followers were fully cognizant of their uses of words whose meanings had been obscured by Catholic misreadings, and of their need to redefine the exact relations between signifiers and signifieds. Hence, the fact that both linguistic systems - "the Calvinist idiom" and "the Catholic idiom" - used the same characters, presented Calvin and his followers in France and Geneva with a unique challenge. Their new language was constructed through the adaptation of the signifiers of a rival culture and system of belief to represent new signifieds. ${ }^{3}$ But first generation French Calvinists, the people who both invented and used the new language, had been brought up on the old faith and language. They themselves inhabited the world of the Catholic language, and shared its discursive system and its prescribed uses of signifiers. Consequently, Huguenots had to adjust themselves to the new meanings which were attributed in their new language to the old words. This challenge was shared by all partisans of the new culture, theologians as well as peasants, intellectuals as well as ordinary people.

In this paper I argue that there were persistent usages of key Catholic words in the theology and cosmology of the early Huguenot believers regardless of their level of education or commitment to the cause. As we shall see, prior cultural and linguistic traditions unavoidably influenced Huguenots' sensibilities and the ways they interpreted their world. While Calvinist theology did, indeed, present a linguistic anti-system to the Catholic system, the rupture from traditional usage of words was more difficult than has usually been assumed by historians of Calvinism. The continuity of linguistic usages indicates a continuity of epistemological perceptions.

One of the major theological and linguistic differences between the old and the new languages was the use of the words "miracula" (miracle) and 
"mirabilia" (marvel). According to common knowledge, Protestant theology dismissed the reliability of post-Biblical miracles and argued the cessation of miracles by the time of the apostles. Comparing Catholic priests to Egyptian magicians, Calvin himself attributed all contemporary miracles to "sheer

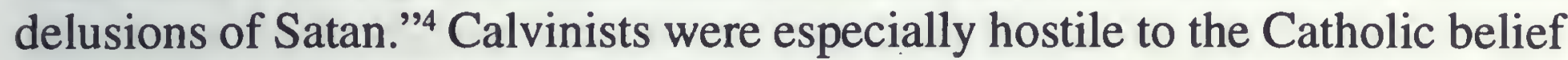
in the power of miracle workers (known previously, in the Catholic system, as saints) to perform miracles, and considered it idolatrous of living people to believe that prayers should be directed to anyone but Christ. They vehemently attacked Catholic prognosticators and divines, whose blood was fair game, "punissable par tout droit divin et humain." Astrologers they regarded as sorcerers, and their art as a diabolic superstition. ${ }^{6}$ This hostility to "superstition" implied a new theology of the natural order, which did not deny God's unique position above the natural order, but nevertheless categorically rejected astrology, prognostication, and other means of divination. This natural theology argued that God dictated an order in the universe, an order that is complete and does not leave space for unorderly occurrences. But creation continues to be subjected to God's care, which sometimes necessitate direct interventions by God. Thus, for example, the fact that the water of the seas gathered together and created a dwelling place for human kind, or the fact that the sea does not flood the earth, are "illustrious miracle" and "beyond nature," and prove God's power over nature as well as his providence. ${ }^{7}$ While events in the world may appear to us fortuitous, they, in fact, take place within and according to God's plan. ${ }^{8}$

Following Calvin's theological writings, recent historiography has argued that the Calvinists regarded nature as a divine plan, which cannot and should not be changed through human interventions. When historical evidence has shown the persistence of pre-Reformation so-called "superstitious" beliefs and practices among Calvinists, its existence was explained as representing the gap between "learned" and "popular" Calvinisms. The Calvinisation of the common believer was a slow process, it has been argued, but the Calvinist authorities succeeded at the end of the process to eradicate the reliance on, and belief in, the supernatural. ${ }^{9}$ Fierce opposition to miracles notwithstanding, the word "miracle" appears time and time again in Calvinist writings, starting with Calvin himself. Its use by first-generation Reformers has not received much attention from either Calvinist theologians or historians of Calvinist religiosity. Bernard Vogler summarized sixteenth-century Protestants' attitude to contemporary miracles as a "categorical rejection." D.P. Walker, however, presented a more nuanced view, and showed the difficulties Protestants 
encountered in articulating their doctrine of the cessation of miracles. ${ }^{10}$ The following reading of first generation Huguenots' discussions of miracles follows the latter. The rejection of contemporary miracles in theological writings was tempered by a spiritual need to encounter divine signs which would demonstrate the realization of God's plan for the universe and the role of the Calvinist doctrine within this program. While Calvin himself was careful to delineate the difference between his concept of the miraculous from the Catholic understanding of this concept, for some of his followers the distinction was less clear. (In fact, even Calvin himself, as we shall see, employed the word "miracle" in its traditional use.) As Calvin stated in the Institutes of the Christian Religion, Catholics demanded from the Reformers to prove themselves in miracles, signs and wonders. ${ }^{11}$ Challenged by their Catholic adversaries, Calvinists of all level of theological education and training sometimes did make use of miraculous events for religious propaganda. While in their theological writings they rejected the persistence of miracles, in their linguistic usage they maintained a pre-Reformation reliance on miracles to claim the validity of their religious message.

The Calvinist ambivalence toward miracles and other supernatural occurrences is found in a wide array of texts: theological treatises and polemical writings; diaries and poems written by Calvinists; fait divers and the "official" history of French Calvinism. In an attempt to trace cultural or linguistic common usages of words, I have examined a large number of varied texts; from Calvin's own writings to the journal of an anonymous Provençal diarist. The following discussion represents a sample of sixteenth-century French Calvinist writings. The treatment of these texts is segmented, and concentrates on the semantic occurrences of key words such as "miracle," "marvels," "providence," and their synonyms in dispersed Huguenot writings. The selection pays less attention to the differences among the authors and the types of writings, though such differences were, of course, very important. It is my argument that the cosmology and theology of the Huguenots were created and experienced through the "totality" of the uses of specific linguistic expressions. It was through a "thesaurus" of new meanings to existing words that Calvinism both explained and understood itself. This "thesaurus" was not limited to the theological writings of Jean Calvin, but was eclectic. By compiling the occurrences of key words in early Huguenot writings, we can better understand early Calvinism as a lived experience and not just a theology. Finally, it is through this eclecticism that the Calvinist notion of the miraculous is best explained. 
Moshe Sluhovsky / Calvinist Miracles and the Concept of the Miraculous / 9

\section{Calvin on Miracles}

Despite the fact that events called miracula were so closely woven into the texture of Christian experience, thought about miracles remained fixed throughout the Middle Ages, following the arguments first laid down by saint Augustine, and it was to Augustine that Calvin turned in his discussion of the natural order and creation. Augustine argued that there was only one miracle, that of creation, and within this miracle God planted all the possibilities for the future, including the two corollaries of His incarnation and the Resurrection of Christ. ${ }^{12}$ "God himself has created all that is wonderful in this world, the great miracles as well as the minor marvels ... and he has included them all in that unique wonder, the miracle of miracles, the World itself."13 But Augustine went on to explain that human beings were so accustomed to the "natural miracles" that they needed to be provoked to reverence by unusual manifestations of God's power. Therefore God created "events," hidden within the natural order of things, and included within the original creation, which at times cause "miracles" that seem to be contrary to nature but are, in fact, inherent in it. ${ }^{14}$ The difference between "natural" and "miraculous" events is therefore not an ontological but a psychological one. It is humankind's understanding which creates the separation and gives meaning to a wide scope of miracles such as mirabilia, miracula, signa, monstra and prodigia, ${ }^{15}$ all of which are not subject to the usual ways in which Providence acts within nature, but are nevertheless parts of the original plan of creation and therefore subject to the laws of God. The wonders are caused in the human understanding of the order of things; they are miraculous from the beholder's point of view, but natural from God's perspective. Thus, the marvellous and the rarity that provoke our amazement signify order, not disorder. In their extreme, they manifest nature's diversity, and remind us that all of nature is a marvel. ${ }^{16}$

Calvin followed the Augustinian teaching. He developed his theology of miracles during the eucharistic controversy with Lutheran theologians over the nature of the Eucharist, itself a controversy on the separation of the signified and signifier. ${ }^{17} \mathrm{~A}$ total rejection of the reality of "signs," "marks," and "miracles" was, of course, impossible in a religion based upon three miraculous divine interventions in the universe. Indeed, Calvin himself argued that "many miracles are subsumed" in the Eucharist. ${ }^{18}$ The centrality of the Eucharist, however, should not distract us from other revelatory modes through which God was believed to show his concern for his people, aspects which Calvin never tired of emphasizing. Nature itself, "the most beautiful 
theater of the world," is a wonder (mirificam, signa), Calvin stated. ${ }^{19}$ The rotation of the heavens, for example, is "such a miracle that we should be

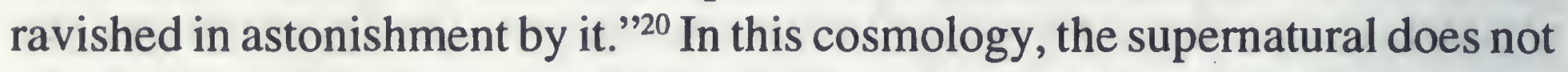
exist as a separate category. Rather, it is encompassed by the natural, as all signs and events are part of the divine plan. God is manifested not only in nature as a whole, but also shows itself in "particular events." ${ }^{21}$ Furthermore, God "often deliberately changes the laws of nature so that we may know that what he really confers is exclusively determined by his will.".22

Calvin, like Augustine before him, widened the concept of the miraculous to include in it the entire universe, which, in its splendor, is a continuous miracle. Both theologians share the same Christian cosmology which recognizes no boundary between "natural" and "miraculous" events. The "miraculous" is, ontologically speaking, as natural as the "natural," and the "natural" is as "miraculous" as the "supernatural." God's secret plan is hidden from us, but well planned and governs all. Any sign which seems to us to be miraculous is in fact as premeditated as any other sign, and it is only our shortcomings which prevent us from realizing it. ${ }^{23}$ Signs and events are in and of themselves not miraculous. The miracle occurs not in nature, but in human spiritual understanding, and is depended on our ability to grasp it, on faith.

Accordingly, God's providence continues to manifest itself. Calvin rejected wonder-workers and traditional "technical" miracles, but not miracles per se: "we [i.e. the new Church] are not entirely lacking in miracles, and these very certain and not subject to mockery."24 These miracles, however, could only be understood through the spirit. Their recognition as miracles is limited to the elect, to members of the "veraecclesia," the people who benefit from God's grace. Only they grasp the cosmic significance of particular signs and events. Their reading of signs reveals that God proves his mighty power through his acts in support of his people. Every event which strengthens the Calvinist church reveals the divine plan, and as such it is a "miracle" and a "sign." These new miracles were as visual to the Calvinist believer as supernatural miracles (the traditional miracles) were to contemporaries, but the "new" miracles were not as extravagant and sensational as medieval miracles. Their visibility was mediated through belief. One system of miracles - visually-marvellous events - whose miraculous nature was self evident, was replaced by another one, in which faith mediated the event and its miraculousness.

Thus, the Reformed Church is both the object which is signified by the miracles, and that which signifies - which determines whether an event is miraculous. The fortifying of the Calvinist Church reveals the miraculous plan of 
Providence at the same time that it testifies to the truthfulness of Calvinist theology. Providence still performs miracles, but no longer through the mediation of individual saints but through the advancement of the True Church.

During the colloquium at Poissy in 1561, Théodore de Bèze summarized for his listeners the main points of the Huguenots' presupposition on miracles. His presentation, which was the only systematic exposition of the Calvinist theology of the miraculous, repeated the main arguments which we have encountered in Calvin's writings: In the new stage in history miracles were no longer necessary to confirm ecclesiastical authority, de Bèze explained. The mere fact that the same men who had burned Reformers during the previous years had since adopted the new religion was in itself a new sign, which testified to the truth of Calvinism. ${ }^{25}$

\section{The Natural as Miraculous}

In both Calvin's and de Bèze's writings, the rejection of miracles was supplemented by a need to "retain a sense of assurance in the midst of historical change," 26 and to decipher contemporary events, first and foremost the growing popularity of the Reformed Church, as miraculous. The detection of the hand of God in historical events was, of course, part of biblical and medieval historiographies. In this Christian tradition history itself was viewed as a revelation, and the study of chronology is based on theological and ideological presupposition. It reveals the logic of the relations between God, the World, and the Reformed Church. ${ }^{27}$

The authors of the Histoire ecclésiastique, the sixteenth-century history of the progress of the Reformed Church, inherited and elaborated this Christian-Calvinist tradition. For them, too, miracles were a natural part of the historical records, and were primarily meant to be edifying. The title "Histoire ecclésiastique" locates the text within a specific historiographical tradition. Eusebius (Historia Ecclesiastica), Bede (Historia ecclesiastica gentis Anglorum) and Hugh of Fleury (Historia ecclesiastica), among others, had used this title previously in their chronicles of the divine revelation through history. In this genre of historical writing, an emphasis was placed on a wide range of mira and prodigia rather than on miracles of saints. Brief stories, curious events, and especially mira of signs and omens supplied the writers of these histories with the same kind of testimonies for the progress of salvation that the miracles of the saints supplied the authors of the Lives of Saints [vitae]. ${ }^{28}$ 
“Etant arrivé le temps que Dieu avoit ordonné pour retirer ses esleus hors des superstitions survenues peu à peu en l'Eglise Romaine," declared the editor(s) in the introduction to the official Calvinist history of their origins, "Dieu commença de faire retentir sa voix à Orleans, Burges \& Tholose." ${ }^{29}$ A new historical age started in which God interferes directly in the world to support his people against the powers of Satan. To the traditional medieval periodization of the law into three periods, namely that of natural law, of Scripture, and of grace, the author seems to add a fourth, the apocalyptic stage, familiar from late medieval writings such as Joachim of Fiore's eschatological prophecies. ${ }^{30}$ This was a historical period of a just judgement and vengeance against the enemies of God and the elect, and a time of victory as a religious act, every obstacle was treated as another example of the devil's resourcefulness, and every success was regarded as God's will. While Calvinists did not share the acute sense of the End which has recently been attributed to Luther and to first-generation Lutherans, ${ }^{31}$ similar eschatological tensions and expectations were apparent in Calvinist historical writings of the sixteenth century. Calvinist authors turned to signs, miracles, and supernatural occurrences, to find in them the guarantees that theirs was the only correct interpretation of the divine plan. History, indeed, supplied them with clear manifestations that divine actions brought salvation to Calvinists and punishment on the Catholics. These divine interventions were repeatedly described in the Histoire ecclésiastique as "miracle" and "miraculous."

One example was the fate of two Huguenot soldiers who were wounded during the battle of Dreux (December 1562). "Après mille estranges adventures," they managed to escape from the battlefield to their nearby village of Dreux and from there to Paris and finally to Orléans, where they were cured. The one showed his healed wound as testimony of a "vray miracle de Dieu." The other, who was hit by a bullet in his loins, was cured so quickly that within three weeks he could once again ride his horse ${ }^{32}$ More impressive is the story of the famous physician Pierre Solery of Aurillac. A bullet crossed his body from one thigh to the other; more bullets entered his shoulders and his chest; another bullet penetrated his kidney and two more lodged in his forehead. Though almost dead, the man did not lose his faith in divine intervention. God sent him assistance in the form of one of Solery's sons, a child of only eight, who carried his father to a nearby village. But Solery's hardships did not end there. The villagers did not want to help him, and he had to continue wandering. But not for long, because "Dieu lui presenta au mesme instant un autre de ses enfants, aagé d'environ dix ans, par lequel souslevé d'autre costé, Dieu voulut 
Moshe Sluhovsky / Calvinist Miracles and the Concept of the Miraculous / 13

qu'il eust assés de force pour arriver en un autre village." The familial drama came to an end with the father's complete cure within a few weeks. In this drama, the author summarized, "Dieu monstra miraculeusement que la vie des siens est en sa main \& non point en celle des hommes." 33

A miraculous salvation also awaited the Huguenot woman from SaintClément-de-Craon, who was thrown into the Poum river afer being tortured in a thousand different ways. "Mais le Seigneur voulait monstrer à l'oeil que nos jours ne sont en la main d'autre que de luy, poussa ceste pauvre femme ainsi vielle \& caduque droit à l' autre bord de la riviere ... le jour suivant Dieu fit un autre miracle à l'endroit de ceste pauvre femme," and saved her from the cruel treatment she received at the hands of the Catholics who found her on the shores of the river. "Un grand miracle de Dieu" also occurred during the martyrdom of Jean Brugère from the village of Formal in the Auvergne. Throughout his execution, while he was "attaché à une chaine de fer," this martyr continued to preach the teaching of the Reformed Church, and even the inquisitor Ory himself regretted the sentence, left the martyr "à demy bruslé," and took to the road to inform other people of this amazing event. ${ }^{35}$

The enemies of the Faith were punished by God in numerous prodigious and miraculous ways. Catholic judges who executed Huguenots died soon after the trial, usually a horrible death. This was the lot of Jean André, "un petit libraire du Palais," and a member of the Confraternity of the Bearers of the Reliquary of Sainte-Geneviève in Paris, who died of a stroke without even having time to confess for his spying on Calvinists. ${ }^{36}$ The same happened to Jean Craneguin, "un ancien avocat," whom God punished with "une maladie de phrenesie merveilleusement estrange" which caused him to see everything that was shown to him as serpents. ${ }^{37}$ The Parisian capitaine du quartier Garget was attacked by a "fievre chaude, courut publiquement par les rues, blasphemant \& invoquant les Diables . . . \& ainsi mourut insensé \& furieux dont ses compagnons ne se faisoient que rire." ${ }^{38}$ Insanity also manifested the just judgement of God in the death of judge Florent Parnjaon, who strangled himself to put an end to his torments. God's retribution sometimes resembled the punishment the judges themselves had afflicted on the Huguenots. The judge and conseiller Laubespin, who was the first to order martyrs' tongues cut out before their execution in order to prevent them from testifying the truth of their religion, was punished on his own tongue. Insects took over his body and settled in his throat, preventing him from eating or drinking. In order to force him to eat, his relatives had to "bridle" his tongue. Tormented and "bailloné," he died in the same torture that he himself had perfected. ${ }^{39}$ 
Deaths of kings acquired special importance in the Calvinist view of history. Two French kings died in the years 1559-1560, and it was difficult to regard this as pure coincidence. In 1559, Henri II died as a result of "le Juste Judgement de Dieu." The following year God "cures the maladies of France" by the death of François II. ${ }^{40}$ The Calvinist poet Jean de la Taille was quick to describe the deaths as "marvellous miracles":

\begin{abstract}
Ces faits divins, ces merveilleux miracles
Roys insensez, malins, sourds, impudens

Vous font scavoir qu'en ces piteux spectacles

Il faut mourrir ou devenir prudens. ${ }^{41}$
\end{abstract}

And a Calvinist diarist from Millau (Cévennes) explained that

En despict de ces deuls, Dieu feüst recogneü per toute la Guaule. Et [Henri II] moreüt l'an 1560, que fust un miracle. Et après ledict Henric, succèda son fils François, lequel fist de plus grans cruautés contre l'Esglise que son dict feu père et moreüst cest année mesmes, que fust un miracle évidant, car moreüst d'une apostume à l'orelle, sens trever remède. ${ }^{42}$

Similarly, the premature death of Charles IX, 14 years later, indicated "qu'il estoibt mort cruellement, d'un flux de sang, tant des partie aultes que baces, dénotant par sela comme pleusieurs avoient profétisé que: qui de sang vit, de sang mort, comme chescun le saict bien."43

The theologians from Geneva who edited the Histoire ecclésiastique and the provincial diary-keeper both kept track of the realization of the Providential plan to establish the city of God on earth. Both wrote down, in d'Aubigné's words, every "accident which helps the realization of the doctrine." 44 The authors of the Histoire ecclesiastique, the committed poet and the humble believer all shared the same eschatological hopes and excitement. Their reading of history was determined by their study of supporting signs of nature. They needed visual proofs of their faith, and found them in testimonies which followed the biblical law, "Wherever hurt is done, you shall give life for life, eye for eye, tooth for tooth, hand for hand, foot for foot, burn for burn, bruise for bruise, wound for wound" (Exodus, 21:23-5). While the cause of death in some of these cases could have been attributed to natural causes, its meaning for the Calvinist believer was clear: Providence supports its elect in different ways, and even a presumably natural death is, in fact, a sign of the divine justice. Similarly, even the iconoclasm in some churches in France and the Netherlands in the 1560s was not an act of man but of God. The Calvinist protector Condé, indeed, felt sorry for the destruction of churches, but 
explained "que cela ne pouvoit estre imputé qu'à un secret mouvement de Dieu." 45 In breaking images, as Phyllis Mack Crew explained, "the iconoclasts in both countries were demonstrating in the most irrefutable and dramatic way possible ... the superiority of the Reformers' miraculous powers, since the ministers were able to commit such scandalous actions against the Church and remain unpunished." ${ }^{46}$ The blending of the natural and the miraculous in these cases points out the new meaning the Reformers ascribed to the concept of "miracle": direct divine interventions in the world in a manner that contradicted the orderly functioning of the universe, but gives visual support to the claim that Calvinism itself is the greatest miracle of this historical stage.

\section{The Miraculous as Natural}

Brilliant, open-minded, creative and controversial, Simon Goulart is one of the more colorful among the sober theologians of Geneva. Goulart was born in Senlis in 1543, and moved to Geneva in 1566, soon after his conversion. Five years after his arrival in the city he was already pastor of the municipal parish of Saint-Gervais, and married to the 15-year-old daughter of Nicolas Picot, a respectable bourgeois of the city and member of the city council, the DeuxCents. Several years later Goulart became a member of the Compagnie de pasteurs. In 1604 he was elected president of the Compagnie, and until 1612, when he resigned, Goulart was "le veritable chef du pouvoir spirituel." ${ }^{47} \mathrm{~A}$ close friend of Théodore de Bèze and Jean Crespin, he participated in the editing of both the Histoire ecclésiastique and the Histoire des Martyrs, and his name appears among the translators of the Genevan Bible of $1588 . \mathrm{He}$ translated works of Seneca, Plutarch, Wier, Calvin, Beza, and François Hotman into French, and found time to compose two monumental histories of events in France in the second half of the sixteenth century: Memoires de l'Estat de France sous Charles Neufiesme (1578) and Mémoires de la ligue (1587-1590), along with more than 70 other works and translations. ${ }^{48}$

In the first decade of the seventeenth century, Goulart published, in Protestant Geneva and ultra-Catholic Paris simultaneously (!), a collection of thousands of "admirable" events which attracted his attention. The collection presents a complex interplay of the natural and the miraculous. ${ }^{49}$ Goulart published whatever he could lay his hands on, Catholic as well as Protestant polemical pamphlets, fait divers and medical treatises, legal cases and occurrences of apparitions. His taste for the bizarre surpassed both his interest in theological controversies and his political and religious loyalties. Goulart 
seldom edited his sources, even when they offered a doctrinal position which contradicted his own confessionalism. In fact, it is not easy to tell from the collection whether the editor was a Calvinist, a Catholic, or a Copt, or whether he was a Frenchman, an Italian, or a subject of the Sultan. All of these religions, cultures, and countries appear side by side in the collection.

In his stories, Goulart did not shy away from morals that were theologically-contested. He included in his collection two cases of resurrection of the dead, in which Egyptian Copts who had been assassinated by their Muslim enemies come back to life. ${ }^{50}$ At another point he wrote that he was ashamed of "offending the eye or the ear of the honest and devoted reader," and therefore refrained from describing words of abuse by an idolatrous man from Clavennes, directed against the name of God and the "bienheureuse vierge Marie."51 Clearly, Goulart spent little time editing and "Calvinizing" his sources. He, in fact, praised himself for not changing "nearly anything" in the stories he collected. ${ }^{52}$ But in light of what we know of the period, his accuracy and tolerance are surprising. We would not expect to find a member of the Company of Pastors so offended by blasphemous words against the Virgin, neither recalling a miraculous resurrection at the very same time that the ability to resurrect was employed by the Catholics to prove the truthfulness of their doctrine against the Calvinists, and was denied firmly by the latter. ${ }^{53}$

Even when Goulart did edit his sources, he used neutral terms. He mentioned on two different occasions two of the Popes' offsprings, a unique opportunity for a Calvinist author to attack the Babylonian fornication of the Catholic Church. Both times Goulart did not add any cynical remark to the idiomatic expression "fils du Pape," as might have been expected from the coeditor of the Histoire des Martyrs. ${ }^{54}$

What can account for Goulart's apparent indifference to the religious controversies of his time? In the numerous dedications to his brother and in the forewords to the reader which introduced each of the volumes, Goulart elaborated his view on the place of the natural and the supernatural in the universe, and added a layer to our understanding of the Calvinist concept of miracles. "Je les appelle Admirables, à cause que les raisons d'une grand part d'icelles sont fort eslongnees de mon apprehension \& qu'il y a du miracle, ce me semble." 55 He recorded in his collection tales of a monstrous birth, a horrible murder, a military victory or a blessed healing, because they all happened due to God's will. God willed them because he wanted us to meditate about the lessons these events teach, and to honor him for all his works. The bizarre and the rare (strange cases of idolatry or a chapter on the prodigious 
appetite of women) testified to the variety of God's interventions in the world. ${ }^{56}$ Whatever shows us the divine order also manifests how difficult it is for human beings to understand God's actions. Whatever causes us to believe in him and to fear him is a miracle, "et voila tout de l'homme."57

The divine plan manifested itself in prodigies and in external signs, which were part of nature, and which together revealed the essence of this plan. Each year, according to Goulart, more unusual events occurred in the world. There have been more plagues, more wars and more times of famine in the sixteenthcentury than ever before, and 35 times during the century apparitions have appeared in the sky. The meaning of each event for itself is hidden from us, but they all were significant, as they were all signs of the just judgement of God who punished the sins of the world. All these occurrences were like the blowing of the trumpets which announce the end of days ${ }^{58}$ The miraculous, the outstanding, and the bizarre, were all contextualized by Goulart within a natural divine order. "In a diversity of ways His grace manifests itself for those who should pay him back."59

Goulart's book enjoyed an immense popularity. Within 20 years it was published in 16 editions in four different languages (French, English, German, and Dutch). According to the book's natural theology, there exists an objective divine order, which does not correspond to the subjective human understanding of the order of things but rather imposes its laws on human disorder. God's active presence in the universe is manifested and narrated through marvellous events which show his grace and his revenge. In compiling the stories, Goulart himself participated in the theological enterprise of bearing witness to the divine order. Human nature, as Augustine and Calvin argued, is weak, and demands continuous affirmation of the divine. Goulart's collection supplied this need. The narration made occurrences meaningful. It rendered them miraculous, and therefore natural; natural, and therefore miraculous.

\section{Supernatural Miracles}

One of the characteristics of the Calvinist miracles which we have examined so far was their "subjective" nature. The death of a French king or a Huguenot military victory were miracles only in the eyes of Calvinist spectators. As we have seen, no boundary was drawn in Calvinist theology between the natural and the miraculous. By widening the concept of the miraculous to encompass the entire universe, Calvinist theologians and believers blended the miraculous with the natural, and argued for the crucial role of faith as a mediation between 
the signified and the signifiers. Direct correlation between sign and meaning did not exist, and the two had to be negotiated through the Spirit, which rendered them meaning.

Nevertheless, in a few incidents Huguenot authors recorded "objective" miracles, namely events when the miraculous nature of signs was beyond dispute. For heuristic reasons, and based on the pattern they all follow, we could name them "biblical miracles." In the biblical miracle, as in all Calvinist miracles, it is God himself who performs the supernatural events. Unlike most Calvinist miracles, however, these are unique in their "objective" visibility: these are divine interventions which can be seen and understood by all to be miraculous. Through these miracles even the non-Calvinist could and should be convinced that God supports the Huguenots against the Catholics.

Towards the end of June, 1558, a group of "ceux de la religion" made their way back from a nightly secret prayer in the fields near Bondes, not far from Blois. At about eleven o' clock at night, a great flame appeared in the sky above them and advanced in front of them to the city, shedding light on the way. Both Calvinist and Catholic citizens of the city verified this divine sign. ${ }^{60}$ On Easter day 1562, the Calvinist preacher Pierre Viret was preaching in Toulouse when suddenly, an hour after he started his sermon, three suns appeared in the sky, creating an arch. A Calvinist from the nearby town of Millau described the three suns: "feürent veüs trois soleills en plein gorn, l'un près de l'autre, de plusieurs colurs. Bien est verai que la coleur rouge supéroit sus toutes autres coleurs; verai est que la un de touts estoit tout roge, colur de sang." 61 The phenomenon of "triple parhelia" was noted a number of times during the sixteenth century. It was a common sign in late medieval and early modern apocalyptic wonder-books, usually taken as a warning and as a fearful sign. French historian Florimond de Raemond regarded it as a clear sign of the coming of heresy. ${ }^{62}$ The appearance of the three suns was therefore followed by expressions of terror. But a medieval tradition also related the appearance of three suns to the birth of Christ and the beginning of a New Age. ${ }^{63}$ The appearance of the sign in Toulouse was thus open for contradictory interpretations. As it turned out, the triple parhelia in this case was a sign for a coming disaster. In the same month there was a massacre of Calvinists at Vassy and the civil war broke out. ${ }^{64}$ Similarly, during the assault on Calvinists in Lyon, in April 1574, big drops of pure blood rained on the city, and public opinion realized that "que s'estoibt un miracle, perce que dens ladite ville avoient respendu beaucoup de sang ignosent des gens de la Religion."65 Finally, in 1575 , a comet, "toute rouge comme de sang," appeared in the sky on two 
different occasions, maybe signifying the blood of the martyrs. ${ }^{66}$

Keeping in mind Calvin's fierce attack of astrology and astrologers, and the opposition to prognosticators in the Histoire ecclésiastique ${ }^{67}$, the direct appeal to astrological evidence testifies to the growing need of these compilers to use divine signs to support their cause. The timing of these astrological references coincided with large scale persecutions of Huguenots, with the outbreak of the first civil war in France, and with the major military defeat at Vassy. The most outstanding miracle of this sort took place in 1573 during the siege of La Rochelle, and is recalled by Goulart, d'Aubigné, and the Calvinist of Millau. "Sur la grande nécessité des Rochelois, le havre fut rempli d'une monstrueuse quantité de sourdons et de pétoncles, ce qu'on n'avoit jamais veu en ce lieu et dont les Réformés ont encore les tableaux en leurs maisons, pour mémoire, comme d'un miracle." ${ }^{68}$ This "marvel," as d'Aubigné calls the event, drew the attention of other Calvinist chroniclers, and its fame reached even the provincial Huguenot of Millau, whose enthusiastic description of the "miraculous event" ["choses miraculeuses"] was filled with exaggerations and magnifications. When the people within the walls started to die of starvation, God sent them a huge quantity of fish which had never before been seen in the area.

Feüst-il cuict à la paoële ou aus charbons ou en quelque sorte que feüst, voire tout cru et fust-il sens sel, lequel avoict un guost admirable, lequel peisson estoibt bon sens pein aussi bien que en pein; vous assurant que ce peisson feüst un grant solagement à tout le peuple, lequel l'on apeloit du sardon, auquel l'on n'avoict iamais plus veü en ce lieu là, sinon per la mer, mais n'estoit pas si beau ni de tel guost. ${ }^{69}$

This lovely dish, a mixture of biblical manna, the miracle of the fish and the loaves, and the delicacies of Provençal cuisine, serves to emphasize the unique character of the supernatural miracles in Calvinist theology. The centrality of the Bible in Calvinist theology was correlated with a return to the use of biblical criteria and images in conducting religious life and in perceiving religious phenomena. The true Church, identified by its return to the purified biblical belief, was supported by biblical miracles. Instead of saints, healers and relics, it was equipped with a cloud of fire, with an arch in the sky, and with manna. God's covenants with Noah, with Moses, and with David were all renewed in this new covenant with the Calvinist. As Goulart stated at the concluding remarks of his Mémoires de l'Estat de France sous Charles Neufiesme: "Les miracles les plus remarquables que Dieu a fait en la conservation des siens en plusieurs milliers d'années, ont esté par luy renouvelez à l'endroit de ceux de la Religion en l'espace de quelques mois."70 Furthermore, 
in their usage of the terms "miracle" and "miraculous" in connection with these events, Calvinist authors reappropriated the condemned and much maligned role of Catholic prognosticators and divines.

As these examples make clear, the overlap of the natural and the miraculous in first-generation Huguenot thought did not entirely erase the existence of contemporary miracles. Nor was the survival of what has been termed "popular" or "superstitious" beliefs among Calvinist believers only the result of a persistence of pre-Reformation traditions. Rather, it was a part of the blending of the miraculous and the natural in Calvinist cosmology. The Genevan theologians Beza, Crespin, Viret and Goulart; the poet d'Aubigné; and the humble believer from the provincial town of Millau, who collects pamphlets and rumours and recorded them in his journal - all shared a belief in a permanent action of Providence in the universe. All looked for visual proofs as testimonies of this action, and all celebrated miraculous events that testified that their cosmology and theology were correct. They all shared a language and culture that concurrently rejected and endorsed miraculous interventions in the world. The Calvinist interpretation of history as a providential act, as a continuous revelation, was shared by all Calvinists (and in fact, by all Christians), and was articulated originally by Calvin himself. The return to this Pentateuchal perception of God, and the renewal of this and other patristic traditions, all added up to the creation of a sacred theatre of the universe in which the sacred and the desecrated, the divine and the diabolical, the Calvinist and the Catholic fought the last battle. Victory belonged to the Calvinist, and specific signs within this setting demonstrated it. In deciphering the meaning of these signs, and rendering them miraculous, the Calvinist reintroduced the miraculous into God's natural plan. More importantly, they located the Calvinist Church itself as the major miracle in the divine plan.

\section{Hebrew University of Jerusalem}

\section{Notes}

I thank Natalie Z. Davis, Mordechai Feingold, Bryant Simon and the referee for this journal for their helpful comments on earlier versions of this paper.

1. On the varieties of Calvinisms see Menna Prestwich, ed., International Calvinism, 15411715 (Oxford: Clarendon, 1985).

2. I am following J.M. Lotman and B. Uspensky's definition of culture as "a system of signs" in their "On the Semiotic Mechanism of Culture," New Literary History 9:2 (1978), p. 211. Cf. Lotman's "The Poetics of Everyday Behavior in Russian Eighteenth Century Culture" 
in Ann Shukman (ed.), The Semantics of Russian Culture (Ann Arbor: Department of Slavic Languages and Literatures, University of Michigan, 1984), p. 231. Denis Crouzet has recently used a similar image, and discussed Catholicism and Calvinism as "two texts." Les guerriers de Dieu. La violence au temps des troubles de religion (Seyssel: Champ Vallon, 1990), vol. 1, p. 102.

3. S. Ullman, Semantics: An Introduction to the Science of Meaning (Oxford: Blackwell, 1973), ch. 3. Ullman's definition follows Ferdinand de Saussure's distinction between langue and parole. See Course in General Linguistics (New York: McGraw-Hill, 1966).

4. "Merae sunt satanae illusiones." Jean Calvin, Institutes of the Christian Religion (1559), ed. by J.T. McNeill, tr. by F.L. Battles, 2 vols. [Philadelphia: Library of Christian Classics, 1960), I, "Prefatory Address to King Francis," pp. 17-18 [cited below as Inst.]; Ioannis Calvini Opera quae supersunt omnia, eds. W. Baum, E. Cunitz and E. Reuss. (Brunswick, 1863-1900), vol. 2, col. 17 [hereafter CO].

5. [Théodore de Bèze], Histoire ecclésiastique des églises réformées au royaumes de France, eds. W. Baum and E. Cunitz, 3 vols. (Paris, 1883-89), III, p. 51 [hereafter His. Ecc.].

6. Jehan Calvin, Traicté ou advertissement contre l'Astrologie, qu'on appelle judiciaire et autres curiositez qui règnent aujourd'hui au monde (Geneva, 1549), pp. 4-9.

7. For a detailed discussion of Calvin's theology of the Natural Order see Susan E. Schreiner, The Theater of his Glory. Nature and the Natural Order in the Thought of John Calvin (Durham, NC: Labyrinth Press, 1991), pp. 7-37.

8. Inst. I, 16:9 (p. 208).

9. There is no systematic study of popular Calvinism, but see anecdotal evidence in J. Estèbe and B. Vogler, "La genèse d'une société protestante: étude comparée de quelques registres consistoriaux languedociens et palatins vers 1600," Annales E.S.C., 31 (1976), pp. 372-3; W.H. Monter, "The Consistory of Geneva, 1559-1569" Bibliothèque d'Humanisme et Renaissance, 38 (1976), pp. 480-1; P. Joutard, "Protestantisme populaire et univers magique: le cas cévénol," Le monde alpin et rhodanien, 5 (1977), pp. 145-171; J. GarrisonEstèbe, Protestants du midi, 1559-1598 (Toulouse: Privat, 1980), pp. 142-7.

10. B. Vogler, "La Réforme et le concept de miracle au XVI ${ }^{\text {ème }}$ siècle," Revue du l'histoire de la spiritualité, 48 (1972), p. 145; D. P. Walker, "The Cessation of Miracles" in Hermeticism and the Renaissance. Intellectual History and the Occult in Early Modern Europe, eds. Ingrid Merkel and Allen G. Debus. (Washington, London and Toronto: Folger Shakespeare Library, 1988), pp. 111-124.

11. Inst. "Prefatory Address to King Frances," p. 16; CO, II: 15.

12. Saint Augustine, City of God, tr. by H. Bettenson (Hammondsworth: Penguin Books, 1972), 22.8, p. 1034.

13. Ibid., 21.9, p. 985.

14. Ibid., 22.8, pp. 1033-1047.

15. Ibid., 21.8, p. 982. 
16. On the concept of the marvel in the Renaissance see Jean Céard, La nature et les prodiges. L'insolite au XVI' siècle en France (Geneva: Droz, 1977); idem, "The Crisis of the Science of Monsters" in Humanism in Crisis. The Decline of the French Renaissance, ed. Philippe Desan. (Ann Arbor: University of Michigan Press, 1990), pp. 181-205. On the marvellous in Lutheran theology see Robin Bruce Barnes, Prophecy and Gnosis. Apocalypticism in the Wake of the Lutheran Reformation (Stanford: Stanford University Press, 1988).

17. See Bernard Cottret, "Pour une sémiotique de la réforme," Annales E.S.C., 39:2 (1984), pp. 265-285.

18. Inst. IV:17:24 (p. 1390): CO II:1023: "In his paucis verbis qui non sentit multa subesse miracula, plus quam stupidus est."

19. Inst. 1:5:2 (pp. 53-54); CO, 1I:42.

20. "Commentary on Psalms 104" COXXXII:94; quoted and translated in William J. Bouwsma, John Calvin. A Sixteenth Century Portrait (New York and Oxford: Oxford University Press, 1988), p. 166. Cf. "Commentary on Psalms 22" CO XXXI:226 on childbirth as a miracle. See also Inst. I:14:21 (p. 181); CO 2:133: "For there are as many miracles of divine power, as many tokens of goodness, and as many proofs of wisdom, as there are kinds of things in the universe, indeed, as there are things wither great or small." Cf. Dewey J. Hoitenga, Faith and Reason from Plato to Plantinga: An Introduction to Reformed Epistemology (Albany: State University of New York Press, 1991), pp. 150-157.

21. Inst. I: 16:7, (p. 205.); CO II:150: "particulares eventus." Cf. Inst. I:13:13, (p. 136): "How plainly and clearly is His deity shown in miracles." CO II:100: "In miraculis autem quam perspicue luculenteque apparet."

22. "Commentary on Genesis 48," CO, XXIII:585.

23. Sermon 12 on the Harmony of the Three Gospels' CO XLVI:141; "Sermon 12 on Deuteronomy 2" CO XXVI:25. Richard Stauffer, Dieu, la création et la Providence dans la prédication de Calvin (Berne, Francfort and Las Vegas: Peter Lang, 1978), pp. 261-275.

24. Inst. "Prefatory Address to King Frances," p. 17; CO II:17: "miracula ergo nobis minime desunt, eaque certa nec cauillis obnoxia."

25. His. Ecc. I, pp. 643-644.

26. I have borrowed the term from R.B. Barnes, Prophecy, p. 114.

27. C.-G. Dubois, La conception de l'histoire en France au XVIe siècle, 1560-1610 (Paris: A.G. Nizet, 1977), pp. 40-41.

28. B. Ward, Miracles and the Medieval Mind (Philadelphia: University of Pennsylvania Press, 1982), pp. 201-213.

29. His. Ecc. I, pp. 1, 8-9, 17.

30. A. Funkenstein, "Periodization and Self-Understanding in the Middle Ages and Early Modern Times," Medievalia et Humanistica, 5 (1974), pp. 10-11. Other divisions of history into distinct periods were also common in this period. See Barnes, pp. 103-115. The following discussion was influenced by Barnes' discussion of Lutheran eschatology. 
31. Barnes, Prophecy; Paola Zambelli, ed., "Astrologi hallucinati": Stars and the End of the World in Luther's Time (berlin and New York: W. de Gruyter, 1986); Heiko A. Oberman, Luther: Man between God and the Devil (New Haven and London: Yale University Press, 1989).

32. His. Ecc. II, p. 312.

33. Ibid., II, 565-566.

34. Ibid., II, 672-3. Was it the same woman who was saved twice by employing the "miraculous force and wisdom God had provided her with"? See p. 679.

35. Ibid., I, p. 73.

36. Ibid., I, p. 72.

37. Ibid., I, pp. 76-7.

38. Ibid., II, p. 597.

39. Ibid., I, pp. 411-412. Additional examples of "la miséricorde de Dieu" appear in His. Ecc. I, pp. 83, 102, 335-7; II, 494, 504, 516, and 518. See also Jean Crespin, Histoire de martyrs persecutéz et mis à mort pour la verité de l'evangile (Geneva, 1619), ed. Daniel Benoît, 3 vols. (Toulouse, 1885) , vol. I, pp. 363-4; III, p. 712; Mémoires de Condé, 6 vols. (London, 1743-45), pp. 591-4. The Protestant poet Agrippa d'Aubigné recorded the story of JeanMarie Trombaut, a judge from Piemont, whose nose was eaten by a wolf because he had ordered a pastor's nose cut off. Agrippa d'Aubigné Histoire universelle, Book II, ch. 11, 8 vols. (Geneva: Droz, 1981), vol. 1, p. 243. See there pp. 239-243, for a list of other "biblical" punishments. Finally, compare to d'Aubignés "Vengeances," part four of Les Tragiques, vv. 769-1132, in Oeuvres (Paris: Pléiade, 1966), pp. 206-214.

40. Hist. Ecc. I, 269, 375.

41. "Tombeau du Roy Françoys II" in J. Pineauz, La poésie des Protestants de langue française du premier synode national jusqu'à la proclamation de l'édit de Nantes (1559-1598) (Paris: Klincksieck, 1971), p. 24.

42. Mémoires d'un Calviniste de Millau, ed. J.-L. Rigal, Archives historiques du Rouergue II (Rodez: Carrère, 1911), p. 472. And see Ibid., p. 12, the diarist's description of François II's death: "Notés que en ces temps ci, le roy [François II] fasoipt de grans persécutions et exécutions contre seus de la Religion ... et s'il heüse vescu davantage ou que Dieu ne lui eüst reteneü la bride, il ne heüsse laissé homme de la Religion sus la terre ... Car Dieu ne put soufrir telles choses: incontinant [Die]u lui manda son héraut de sa justicie que [lui envoya] une apostumme en une aurelle qui i avoict doleurs intollérables; lequel Roi moreüt, le sixiesme jorn du mois de désambre, 1560."

43. Ibid., p. 304.

44. Agrippa d'Aubigné, Histoire universelle, vol. 1, p. 243.

45. His. Ecc. II, p. 74. Crespin, Histoire de Martyrs, III, 521: "Jugement merveilleux \& providence de Dieu"; p. 522: "ç’a esté le doigt \& la puissance de Dieu qui a fait ceci." 
46. P. Mack Crew, Calvinist Preaching and Iconoclasm in the Netherlands, 1544-1569 (Cambridge: Cambridge University Press, 1978), pp. 26-7.

47. Leonard Chester Jones, Simon Goulart, 1543-1628 (Geneva and Paris: Georg/Champion, 1917), p. 248. This is still the only biography of Goulart, but see Robert M. Kingdon, Myths about the St. Bartholomew's Day Massacres, 1572-1576 (Cambridge, MA, and London: Harvard University Press, 1988), for a discussion of Goulart's Mémoires de l'estat de France sous Charles IX.

48. A detailed bibliography of Goulart's 75 (!) works appears in Jones, pp. 553-650.

49. The collection has not enjoyed much attention from scholars. There is a short discussion of it in Rudolf Schenda, "Die französische Prodigienliteratur in des Zweiten Hälfte des 16. Jahrhunderts," Münchner Romanistische Arbeiten XVI (1961), pp. 84-9.

50. Simon Goulart, Histoires admirables et memorables de notre temps. Recueillies de plesieurs Autheurs, Memoires \& Avis de divers endroits (Paris, 1707), p. 34.

51. Ibid., pp. 25-6.

52. Ibid., p. 3, "Adertissement au lecteur."

53. H. Platelle, Les Chrétiens face au miracle. Lille au XVI siècle (Paris: Cerf, 1968), pp. 4870; M. Bernos, "Réflexions sur un miracle à l'Annonciade d'Aix-en-Provence," Annales du Midi, 82, (1970), pp. 5-20.

54. Simon Goulart, Thresor d'histoires admirables et memorables de nostre temps, 2 vols. (Geneva, 1620), II, pp. 894 and 938. Goulart's source is Francesco Guicciardini's Storia d'Italia, book I, ch. 3 and book VI, ch. 4 (Turin: Einaudi, 1971), vol. 1, pp. 20-21 \& 554555.

55. Histoires, p. 3; cf. Thresor, vol. 1, p. 4 (Italics added).

56. Histoires, pp. 8-26; 47-56.

57. Ibid., p. 3.

58. Ibid., pp. 81-2.

59. Thresor, vol. 2, p. 557.

60. His. Ecc., I, p. 175.

61. Calviniste de Millau, p. 39.

62. Florimond de Raemond, Histoire de la naissance, progrez et décadence de l'Hérésie de ce siecle divisée en huit livres (Paris, 1605), book I, ch. 2, fol. 7. For additional examples see Ottavia Niccoli, Prophesy and People in Renaissance Italy (Princeton: Princeton University Press, 1990), pp. 185-188.

63. According to Niccoli, the prodigy was part of the repertory of exempla of late medieval preaching; Ibid., p. 186, note 49. Barnes, pp. 82-93, discusses its appearance in Lutheran wonder-books. On articles by Krzysztof Pomian and John D. North in P. Zambelli (ed.), "Astrology hallucinati", pp. 29-100. 
Moshe Sluhovsky / Calvinist Miracles and the Concept of the Miraculous / 25

64. His. Ecc., III, pp. 163-4.

65. Calviniste de Millau, p. 299.

66. Ibid., pp. 349-50.

67. See n. 4-5 above.

68. D'Aubigné, Histoire universelle, book V, ch. 11, p. 35; cf. Goulart, Mémoires de l'estat de France sous Charles Neufiesme, vol. 2 (Middlebourg, 1578), II, pp. 293v-294r: "Il ne faut passer sous silence la prouision de viures que Dieu leur fournit lors que les munitions ordinaries commencerent à defaillir, c'est asauoir numbre infini de menus poissons qui se venoient comme rendre à la merci de ces assieges."

69. Calviniste de Millau, pp. 265-6.

70. Goulart, Mémoires, p. 783. 